UDC: 616.1

DOI: 10.32345/USMYJ.3(111).2019.32-46

\title{
Черняєва Катерина
}

Асистент кафедри внутрішньої медицини №2 НМУ імені О.О. Богомольця

Руденко Юлія

Д.мед.н., професор кафедри внутрішньої медицини №2 НМУ імені О.О. Богомольця

Мостбауер Галина

К.мед.н., доцент кафедри внутрішньої медицини №2 НМУ імені О.О. Богомольця

Безродний Андрій

К.мед.н., доцент кафедри внутрішньої медицини №2 НМУ імені О.О. Богомольця

Шевчук Михайло

Асистент кафедри внутрішньої медицини №2 НМУ імені О.О. Богомольця

Саблін Андрій

Завідувач інфарктним відділенням №2 Олександрівської клінічної лікарні м. Києва

Москаленко Юлія

Асистент кафедри внутрішньої медицини №2 НМУ імені О.О. Богомольця

Ковтун Євген

Асистент кафедри внутрішньої медицини №2 НМУ імені О.О. Богомольця

\section{ПОКАЗНИКИ СТРУКТУРНО-ФУНКЦІОНАЛЬНИХ ЗМІН МІОКАРДА, ЯК ПРЕДИКТОРИ РОЗВИТКУ ФІБРИЛЯЦІї ПЕРЕДСЕРДЬ У ХВОРИХ НА СЕРЦЕВУ НЕДОСТАТНІСТЬ ЗІ ЗБЕРЕЖЕНОЮ ФРАКЦІЮ ВИКИДУ ЛІВОГО ШЛУНОЧКА}

\begin{abstract}
Анотація. Велика кількість досліджень, проведених останнім часом свідчать, що фібриляцію передсердь (ФП) та сериеву недостатність (СН) потрібно розглядати, як дві епідемічні сериево-судинні патології, які тісно взаємопов'язані між собою, причому кожна з них сприяє розвитку іншої. Метою проведеної нами роботи було проаналізувати особливості структурно-функиіонального стану серия і судин у хворих на СНзбФВ, а також визначити найбільш інформативні предиктори розвитку ФП та їх прогностичну иінність. Вивчення літературних джерел засвідчє, щзо ФП має тісний зв'язок як з СНзбФВ, так і з діагностичними критеріями, які використовуються для ї визначення. Актуальність дослідження даної патології полягає в тому, що ФП має значний вплив на перебіг та прогноз при СНзбФВ. Дослідження проведено за дизайном «випадок-контроль». Наукова праия основана на опрацюванні результатів обстенення 115 гемодинамічно стабільних пацієнтів з артеріальною гіпертензією (АГ), клінічним симптомами і ознаками сериевої недостатності (CH), фракиією викиду (ФВ) тівого шлуночка (ЛШ) $\geq 50 \%$ та ознаками діастолічної дисфункцї (ДД) ЛШ за даними ЕхоКГ. Вік хворих склав від 40 до 85 років (середній вік 66,3 \pm 10,8 роки). Вперше були проаналізовані критеріі діастолічної дисфункиії лівого шлуночка в якості можливих предикторів розвитку фібрилячії передсердь у хворих з СНзбФВ та визначені орієнтовні порогові значення. Дослідження емпірично підтверджує та теоретично доводить, що
\end{abstract}

Cite as: Cherniaieva K., Rudenko Y., Mostbauer G., Bezrodniy A., Shevchuk M., Sablin A., Moskalenko Y., Kovtun E. Indicators of structural and functional changes in the myocardium as predictors of the atrial fibrillation in patients with heart failure and preserved ejection fraction

Ukrainian scientific medical youth journal, issue, 4(112), $2019 \quad$ DOI: 10.32345/USMYJ.3(111).2019.32-46 
наявність фібриляиії передсердь у пацієнтів з СНзбФВ на відміну від збереження синусового ритму, асоціюється з важчим ФК по класифікації NYНА; вищим на 28,1\% рівнем NTргоBNP; зі збільшенням тиску наповнення лівого шлуночка з орієнтовними пороговими значеннями ІОЛП>40 мл/м2 та Е/e’>14,75 у.о.; з порушенням ендотелій-залежної вазодилатації та початковим зниженням швидкості клубочкової більтрації. Результати проведеного дослідження можуть бути корисними для своєчасного виявлення ФП у пачієнтів з встановленою СНзбФВ, иляхом скринінгового проведення добового моніторингу ЕКГ, за умов виявлення становлених нами порогових значень показників діастолічної дисфункції ЛШ.

Ключові слова. артеріальна гіпертензія, артеріальна жорсткість, діастолічна дисфункція, серцева недостатність, фібриляція передсердь.

Вступ. Хронічна серцева недостатність $(\mathrm{CH})$ розвивається при різних значеннях фракції викиду (ФВ) лівого шлуночка (ЛШ). За показниками фракції викиду лівого шлуночка виділяють пацієнтів зі збереженою $(\geq 50 \%)$, помірно зниженою (40-49\%) і зниженою (<40\%) ФВ ЛШ (Ponikowski P. et al., 2016).

Клінічні дослідження патогенезу та лікувальних тактик СН продовжують проводитись і далі (Lund L.H. et al., 2014). Згідно накопичених на даний момент результатів стає зрозумілим, що патогенетичні механізми $\mathrm{CH}$ із збереженою і зниженою ФВ ЛШ частково збігаються, однак препарати та їх комбінації, які довели свій вплив на виживання при СН зі зниженою ФВ ЛШ, не мають такого ефекту у хворих на СН зі збереженою ФВ (Cleland J.G. et al., 2014). Через те, $є$ припущення, що лікувати та впливати на прогноз СНзбФВ можливо лише шляхом контролю чинників (захворювань), які, імовірно, стали основою для іiі розвитку та прогресування. Одним з таких чинників $є$ фібриляція передсердь, яка $€$ найбільш поширеним порушенням ритму у хворих на серцеву недостатність зі збереженою фракцією викиду лівого шлуночка, з частотою виявлення від 20 до 40\%, незалежно від стадії CH (C.S. Lam et al., 2011).

Огляд літератури. Серцева недостат- ність із збереженою фракцією викиду (СНзбФВ) лівого шлуночка (ЛШ) і фібриляція передсердь (ФП) - це два патологічних стани, що часто співіснують і мають спільні клінічні особливості (Zile M.R. et al., 2015). СНзбФВ, як і ФП, асоціюється зі старшим віком, артеріальною гіпертензією і діастолічною дисфункцією ЛШ (Quinones M.A., 2005). Проведені клінічні дослідження не змогли диференціювати, що $є$ першочерговим - СНзбФВ або ФП, і в клінічній практиці існують чіткі діагностичні проблеми.

Найбільш поширеним механізмом розвитку ФП у хворих на СНзбФВ $є$ структурне ремоделювання та електрофізіологічні порушення лівого передсердя (ЛП). Об’єм ЛА на 68\% більший у пацієнтів з СНзбФВ порівняно із співставними за віком суб'єктами контрольної групи та на 40\% більше, ніж у пацієнтів з гіпертонічною хворобою без $\mathrm{CH}$ (Naeje R. et al. 2013). Пацієнти з СНзбФВ мають зменшену фракцію спорожнення ЛП і скорочувальний резерв у порівнянні з контрольною групою суб’єктів та пацієнтами 3 артеріальною гіпертензією. Дилатація ЛП при СНзбФВ є доведеним проаритмічним субстратом, який пов'язаний з фіброзом передсердь (Knacktedt C. et al. 2008). В свою чергу, діастолічна дисфункція з порушенням релаксації лівого шлуночка, як 
K. Cherniaieva, Y. Rudenko, G.Mostbauer, A. Bezrodniy, M. Shevchuk, A. Sablin, Y. Moskalenko, E. Kovtun Indicators of structural and functional changes in the myocardium as predictors of the atrial fibrillation in patients with heart failure and preserved ejection fraction

основна ознака СНзбФВ, призводять до збільшення тиску в лівому передсерді та вимагають більш ефективного скорочення передсердь для підтримки нормального наповнення лівого шлуночка (Nagueh S.F. et al., 2009).

Оскільки сама ФП викликає розширення порожнини ЛП, порушення його функції і фіброз, ФП може бути безпосередньою причиною СНзбФВ (Амосова Е.Н и др., 2018). Відомо, що успішна кардіоверсія асоціюється зі збільшенням передсердного внеску у наповнення лівого шлуночка з 30\% до 47\% протягом 1 місяця після відновлення синусового ритму (McKelvie R.S. et al., 2010). ФП також пов'язана з фіброзом міокарда ЛШ (Kristensen S.L. et al., 2019), що, у свою чергу, сприяє діастолічній дисфункції ЛШ і розвитку СНзбФВ (Rosita Z. et al., 2013). Крім того, ремоделювання атріовентрикулярного кільця з прогресуючою мітральною і трикуспідальною регургітацією може бути іншим механізмом, за допомогою якого ФП викликає СНзбФВ (Manning W.J. et al., 1994). Крім того, виснаження запасів передсердного натрійуретичного пептиду, яке може виникати при постійній ФП, призводить до вазоконстрикції і застійним явищам, що може ініціювати СНзбФВ (Ahmed A. et al., 2007).

ФП ускладнює діагностику СНзбФВ. Остання характеризується поєднанням: клінічних симптомів та ознак з відповідним органічним ураженням серця або об’єктивно підтвердженою діастолічною дисфункцією ЛШ та підвищеним рівнем $\mathrm{N}$-типу термінального мозкового натрійуретичного пептиду (ATS, 2002). Ці параметри доволі важко встановити та оцінити за наявності ФП, тому що симптоми ФП схожі на прояви СНзбФВ, параметри діастолічної функції складно отримати, а рівень натрійуретичного пептиду може підвищуватись навіть за відсутності $\mathrm{CH}$. Окремим питанням є ступінь підвищен- ня NT-proBNP, адже чітко визначеного рівня для цього маркеру у хворих на $\mathrm{CH}$ в поєднанні з ФП не існує. Навіть такі багатоцентрові масштабні дослідження як SOKRATE-Preserved та PARAGON-HF в своїх критеріях $\mathrm{CH}$, використаних для відбору хворих, значно відрізняються по пороговому значенню NTproBNP у пацієнтів з ФП. Так в дослідженні SOKRATEPreserved підвищеним вважався рівень NTproBNP > 600 пг/мл, а в дослідженні PARAGON-HF -> 900 пг/мл.

Враховуючи вищезазначене, існує необхідність більш детального вивчення відмінностей в структурі та функції ЛШ та міокарда в цілому у хворих на СНзбФВ з ФП і з синусовим ритмом (СР), та визначення критеріїв стратифікації ризику розвитку ФП у пацієнтів з СНзбФВ.

Метою нашого дослідження було проаналізувати особливості структурно-функціонального стану серця і судин у хворих на СНзбФВ, а також визначити найбільш інформативні предиктори розвитку ФП та їх прогностичну цінність.

\section{Методологія та методи дослідження.} У дослідження залучено 115 гемодинамічно стабільних пацієнтів з діагнозом СН зі збереженою ФВ II або III функціонального класу (ФК) за NYHA. Серед пацієнтів було 67 (55,8 \%) чоловіків і 53 (44,2 \%) жінки. Середній вік - $(67,3 \pm 9,7)$ років. Діагноз СН зі збереженою ФВ установлювали згідно з рекомендаціями Європейського товариства кардіологів (ЄТК, 2016) за наявності відповідних симптомів і клінічних ознак, ФВ ЛШ $\geq 50 \%$, рівня $\mathrm{N}$-термінального фрагмента мозкового натрійуретичного пептиду (NT-proBNP) $>125$ нг/мл та наявності не менше 1 із 3 критеріїв: збільшення індексу маси міокарда ЛШ (ІММЛШ) з урахуванням статі, індексу об'єму лівого передсердя (ІОЛП) $>34$ мл/ $\mathrm{M}^{2}$, середнього е' < 9 і Е/e'> 13.

Критерії залучення: вік >18 років, $\mathrm{CH}$ II стадії (за класифікацією Стражеска - 
K. Cherniaieva, Y. Rudenko, G.Mostbauer, A. Bezrodniy, M. Shevchuk, A. Sablin, Y. Moskalenko, E. Kovtun Indicators of structural and functional changes in the myocardium as predictors of the atrial fibrillation in patients with heart failure and preserved ejection fraction

Василенка), II — III ФК NYHА з ФВ ЛШ $>50 \%$ та наявність гіпертрофії ЛШ та/ або дилатації ЛП, та/або ознак діастолічної дисфункції ЛШ за даними допплерехокардіографії (допплер-ЕхоКГ) згідно з рекомендаціями ЄТК (2016), підписана інформована згода пацієнта на участь у дослідженні.

Критерії виключення: вік понад 85 років, резистентна АГ, вторинна АГ, АГ 3 ступеня, тахісистолічний варіант фібриляції передсердь (ФП), атріовентрикулярна блокада II - III ступеня, синдром слабкості синусового вузла, вроджені та набуті вади серця, часті ектопічні аритмії, стабільна стенокардія вище II ФК з потребою в короткодіючих нітратах більше ніж тричі на тиждень, некоронарогенні захворювання міокарда, легенева артеріальна гіпертензія, венозний тромбоемболізм, міокардит, перикардит, хронічне захворювання нирок (ХЗН) зі швидкістю клубочкової фільтрації (ШКФ) < 30 мл/ хв/1,73м2, декомпенсовані супутні некардіальні коморбідні захворювання: хронічне обструктивне захворювання легень (ХОЗЛ) з обструкцією III - IV ступеня, неконтрольована бронхіальна астма, анемія $з$ рівнем гемоглобіну < 90 г/л, декомпенсований цукровий діабет (ЦД) та ураження опорно-рухового апарату, які лімітують толерантність до фізичного навантаження.

Для виконання поставленої мети пацієнтів розподілили на дві групи. До 1-ї групи було включено 85 пацієнтів з СНзбФВ та синусовим ритмом, до 2-ї групи було включено 35 хворих з СНзбФВ та ФП, серед яких 7 (20\%) з персистуючою ФП та 28 (80\%) $з$ постійною формою ФП.

Обстеження, крім загальноклінічного рутинного лабораторного, передбачало розрахунок ШКФ за формулою CKD-EPI, визначення імуноферментним методом рівня NT-proBNP; тест 6-хвилинної ходьби, проведення допплер-ЕхоКГ.
Проаналізовано частоту некардіальних коморбідних станів, діагностованих раніше або вперше виявлених під час обстеження (цукрового діабету 2 типу, анемія, ожиріння, хронічного захворювання нирок (ХЗН), хронічне обструктивне захворювання легень з обструкцією I - II ступеня). Трансторакальну ЕхоКГ виконано на ультразвуковому обладнанні ProSound-5000 (Aloka, Японія) за загальноприйнятою методикою з визначенням ФВ ЛШ, індексу об’єму лівого передсердя (ІОЛП), індексів кінцеводіастолічного і кінцевосистолічного об’єму (КДІ і КСІ) за Simpson, товщини стінки лівого шлуночка (ТСЛЖ), ІММ ЛШ, діаметра правого шлуночка (ПШ) в апікальній 4-камерній позиції. За допомогою допплер-ЕхоКГ визначали швидкість потоку трикуспідальної регургітації і систолічний тиск у легеневій артерій (СТЛА), параметри трансмітрального кровотоку (час уповільнення раннього діастолічного потоку (DT), час ізоволюмічного розслаблення (IVRT), швидкість раннього діастолічного трансмітрального потоку Е і пізнього потоку А, з розрахунком співвідношення Е/A). Методом тканинної допплерографії визначали е'лат, е'септ з подальшим розрахунком середнього е' і Е/е’. Розраховано тиск заклинювання легеневих капілярів (ТЗЛК) за формулою:

$$
\text { ТЗЛК }=\left(1,24 x E / e^{\prime}\right)+1,9
$$

та транспульмонарний градієнт (ТПГ) за формулою (Borlaug B.A. et al., 2011):

$$
\text { ТПГ = середній тиск } в \text { ЛА - ТЗЛК. }
$$

Розраховували ефективну артеріальну жорсткість (Еа) за формулою:

$$
E a=\frac{(0,9 \cdot C A T)}{y O},
$$


де УО - ударний об’єм ЛШ. Кінцево-систолічну жорсткість (Ees) визначали за формулою:

$$
\text { Ees }=\frac{(0,9 \cdot C A T)}{K C O},
$$

де КСО — кінцевосистолічний об’єм ЛШ. Розраховували діастолічний еластанс як співвідношення Е/е' та КДО ЛШ, артеріально-шлуночкове сполучення - як відношення $\mathrm{Ea} / \mathrm{Ees}$ (Vermond R.A. et al., 2015).

Розраховували показники системного судинного опору (ССО) за формулою:

$$
C C O=80 \cdot\left(\frac{\text { Середній АT }}{\text { Серцеввй викид }}\right)
$$

Системний артеріальний комплаєнс (САК) визначали за формулою (Williams B. et al., 2018):

$$
\text { САК }=\frac{\text { УО }}{\text { Пульсовий тиск } . ~}
$$

Маса міокарда ЛШ була розрахована за формулою (Otsuki T. et al., 2006):

$$
\begin{aligned}
& \text { ММЛШ = } \\
& =1,04\left[(К Д Р+М Ш П+3 С Л Ш)^{3}-\text { КДР }^{3}\right]-13,6
\end{aligned}
$$

Гіпертрофію міокарда ЛШ діагностували, якщо ІММЛШ $\geq 115$ г/м ${ }^{2}$ для чо-

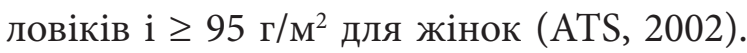
Тест 6-хвилинної ходьби проведено згідно $з$ рекомендаціями Американського торакального товариства (Kotecha D. et al., 2016).

Статистична обробка проведена в програмі IBM SPSS Statistics Base v.22, EZR. Статистичну значущість різниці середніх величин у групах порівняння оцінювали за допомогою непараметричних критеріїв для незалежних вибірок. Для порівняння категорійних змінних використовували - $\mathrm{X}^{2}$-тест. Наявність взаємозв'язку між параметрами, його силу і напрям визначали за ранговим коефіцієнтом кореляції (r). Для оцінки ризику виявлення фібриляції передсердь та визначення порогових рівнів показників застосовувався ROC-аналіз з оцінкою чутливості, специфічності та прогностичної ефективності порогових значень. При використанні будь-яких статистичних методів статистично значущими вважали відмінності при значеннях ризику похибки $\mathrm{p}<0,05$.

Результати i обговорення. Пацієнти були співставні за віком, гендерним складом та антропометричними характеристиками (p>0,05) (таблиця 1). В групі з ФП була більша важкість $\mathrm{CH}$ згідно з клініко-лабораторними даними: III ФК (NYHA) встановлено у 54,3\% хворих 2-ї групи, порівняно з 34,1\% пацієнтів 1 групи $(\mathrm{p}<0,05)$; рівень NT-proBNP в 2 групі - 1084,7 $\pm 317,7$ пг/мл був достовірно вищим ніж у хворих 1-ї групи - 579,2 $\pm 289,4$ пг/м, (p<0,01); дистанція 6-хвилинної ходьби, яку здолали пацієнти 2-ї групи в середньому складала $318,3 \pm 73,3$ м, що було достовірно менше ніж у 1-й - 442,9 \pm 93,6 м $(\mathrm{p}<0,001)$. Аналізуючи частоту коморбідних станів, не виявлено достовірної різниці у частоті цукрового діабету, ХОЗЛ та ожиріння (всі $\mathrm{p}>0,05)$, однак звертає на себе увагу значно нижча ШКФ $(63,6 \pm 11$ проти 74,2 \pm 19,1 мл/хв/1,73 м², $\mathrm{p}<0,001)$ та, як наслідок, більша частота анемії $(25,7 \%$ проти 9,4\%, p<0,05), в групі 3 ФП. (див. табл. 1).

За результатами ЕхоКГ було виявлено ознаки об'ємного перевантаження ЛШ, про що свідчить більший КДІ $(70 \pm 18,3$ проти $67 \pm 12,3$ мл), КСI (33,2 $\pm 11,3$ проти $28,7 \pm 8,2$ мл) та УІ $(39,1 \pm 9,1$ проти $38,1 \pm 6,2$ мл), $\mathrm{p}<0,05-0,01$, та достовірно нижча ФВ ЛШ $(53,4 \pm 5,1$ проти 56,8 $\pm 5,9 \%, \mathrm{p}<0,001), \mathrm{y}$ пацієнтів 2-ї групи, порівняно з 1-ю. Імовірно, початкове порушення систолічної 
K. Cherniaieva, Y. Rudenko, G.Mostbauer, A. Bezrodniy, M. Shevchuk, A. Sablin, Y. Moskalenko, E. Kovtun Indicators of structural and functional changes in the myocardium as predictors of the atrial fibrillation in patients with heart failure and preserved ejection fraction

Таблиця 1. Загальна клінічна характеристика пацієнтів

\begin{tabular}{|c|c|c|c|}
\hline Параметр & Група $1(n=85)$ & Група 2 (n=35) & $\mathbf{P}$ \\
\hline Чоловіки, n (\%) & $49(57,6 \%)$ & $18(51,4 \%)$ & н/д \\
\hline Середній вік, роки & $65 \pm 10,8$ & $68,1 \pm 10,2$ & н/д \\
\hline $\begin{array}{l}\text { IM в анамнезі } \\
\text { в т.ч. Q-IM }\end{array}$ & $\begin{array}{l}41(58,2 \%) \\
27(31,8 \%)\end{array}$ & $\begin{array}{l}5(14,3 \%) \\
5(14,3 \%)\end{array}$ & $\begin{array}{l}\mathrm{p}<0,001 \\
\mathrm{p}<0,05\end{array}$ \\
\hline ЦД 2 типу & $28(32,9 \%)$ & $14(40 \%)$ & н/д \\
\hline ШКФ, мл/ хв/1,73 м² & $74,2 \pm 19,1$ & $63,6 \pm 11$ & $\mathrm{p}<0,001$ \\
\hline ХЗН (ШКФ<60) & $23(27,1 \%)$ & $8(22,9 \%)$ & н/д \\
\hline Анемія & $8(9,4 \%)$ & $9(25,7 \%)$ & $\mathrm{p}<0,05$ \\
\hline ХОЗЛ & $28(32,9 \%)$ & $14(40 \%)$ & н/д \\
\hline $\begin{array}{l}\text { IMT, кг/ } \mathrm{M}^{2} \\
\mathrm{IMT}>30\end{array}$ & $\begin{array}{c}30,3 \pm 5,4 \\
45(52,9 \%)\end{array}$ & $\begin{array}{c}30,8 \pm 6,4 \\
16(45,7 \%)\end{array}$ & $\begin{array}{l}\text { н/д } \\
\text { н/д }\end{array}$ \\
\hline $\begin{array}{l}\text { ФK NYHA } \\
\text { II } \\
\text { III }\end{array}$ & $\begin{array}{l}56(65,9 \%) \\
29(34,1 \%)\end{array}$ & $\begin{array}{l}16(45,7 \%) \\
19(54,3 \%)\end{array}$ & $\begin{array}{l}\mathrm{p}<0,05 \\
\mathrm{p}<0,05\end{array}$ \\
\hline NT-pro BNP, пг/мл & $579,4 \pm 289,4$ & $1084,7 \pm 317,7$ & $\mathrm{p}<0,01$ \\
\hline Дистанція 6XX, м & $442,9 \pm 93,6$ & $318,3 \pm 73,3$ & $p<0,001$ \\
\hline
\end{tabular}

Примітка: н/д - немає достовірності.

функції ЛШ призводить до підвищення тиску в порожнині ЛП з розвитком його дилатації, що результує у більшому ІОЛП $(48,3 \pm 9,9$ та $38,4 \pm 4,5$ мл, $\mathrm{p}<0,001)$ в групі з ФП, порівняно з СР. В той же час, серед пацієнтів 2-ї групи відстежується більш виражена діастолічна дисфункція лівого шлуночка за даними показників тканинної допплерографії - е' септального $(4,1 \pm 0,6$ i $5,2 \pm 1,3, \mathrm{p}<0,001)$, латерального $(4,7 \pm 0,7$ і $6,6 \pm 1,8, \mathrm{p}<0,001)$ та середнього $(4,4 \pm 0,5$ і $5,9 \pm 1,5, \mathrm{p}<0,05)$ та розрахункового показника Е/е' спокою $(16,3 \pm 1,8$ і $13,2 \pm 1,9, \mathrm{p}<0,01)$, що підтверджується кореляцією наявності ФП з тиском наповнення лівого шлуночку (таблиця 2, 3).

Ретроградне перевантаження малого кола кровообігу підтверджується більш виразною легеневою гіпертензією, за даними СТЛА $(53,1 \pm 19,5$ i $32,1 \pm 7,5, \mathrm{p}<0,001)$, ТЗЛК $(22 \pm 2,4$ i $18,3 \pm 2,4, \mathrm{p}<0,001)$, ТПГ $(31,1 \pm 17,8$ і $13,8 \pm 6,4, \mathrm{p}<0,001)$ та середнього градієнту на клапані ЛА $(47,1 \pm 18,8$

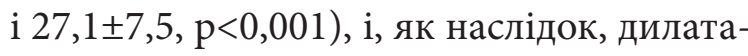
цією правого шлуночка з розвитком відносної недостатності трикуспідального клапана, за даними ШТР $(3,6 \pm 0,7$ і 2,9 0 , 3 , $\mathrm{p}<0,001)$ в групі хворих з ФП, порівняно з хворими із синусовим ритмом. Водночас збільшення цих показників у хворих 2-ї групи могло вказувати на приєднання i реактивної прекапілярної ЛГ. Уточнення внеску реактивної ЛГ потребує безпосереднього вимірювання тиску в ЛА і «легеневих капілярах», що в умовах нашого дослідження не проводилось та $є$ недоліком. Слід зазначити, що підвищення тиску в ЛА характерно і для пацієнтів групи $\mathrm{CP}$, але серед хворих з ФП виявлено значно більшу частоту СТЛА > 45 мм.рт.ст. $(71,4 \%$ i $34,1 \%, \mathrm{p}<0,001)$.

Окремої уваги заслуговує внесок судинного русла у резистивне навантаження на ЛШ, що $є$ невід'ємною ланкою патогенезу СНзбФВ. Нами отримано дані за підвищення судинної жорсткості, згідно 
K. Cherniaieva, Y. Rudenko, G.Mostbauer, A. Bezrodniy, M. Shevchuk, A. Sablin, Y. Moskalenko, E. Kovtun Indicators of structural and functional changes in the myocardium as predictors of the atrial fibrillation in patients with heart failure and preserved ejection fraction

Таблиця 2. Показники структурно-функціонального стану серця у пацієнтів з артеріальною гіпертензією та серцевою недостатністю зі збереженою фракцією викиду з синусовим ритмом та при фібриляції передсердь

\begin{tabular}{|c|c|c|c|}
\hline Параметр & Група $1(\mathrm{n}=85)$ & Група $2(\mathrm{n}=35)$ & $\mathrm{P}$ \\
\hline КДІ, мл/м² & $67 \pm 12,3$ & $70 \pm 18,3$ & $\mathrm{p}<0,01$ \\
\hline KCI, мл/ $\mathrm{M}^{2}$ & $28,7 \pm 8,2$ & $33,2 \pm 11,3$ & $\mathrm{p}=0,006$ \\
\hline УІ, мл/ $\mathrm{M}^{2}$ & $38,1 \pm 6,2$ & $39,1 \pm 9,1$ & $\mathrm{p}<0,01$ \\
\hline ФВ ЛШ, \% & $56,8 \pm 5,9$ & $53,4 \pm 5,1$ & $\mathrm{p}<0,001$ \\
\hline 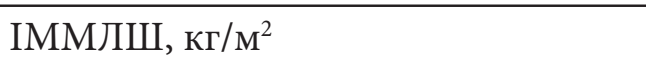 & $181,4 \pm 31,1$ & $188,4 \pm 40,6$ & $\mathrm{p}=0,03$ \\
\hline ІОЛП, мл/м² & $38,4 \pm 4,5$ & $48,3 \pm 9,9$ & $\mathrm{p}<0,001$ \\
\hline $\begin{array}{l}\text { СТЛА, мм.рт.ст. } \\
>45 \text { мм.рт.ст., (n, \%) }\end{array}$ & $\begin{array}{l}32,1 \pm 7,5 \\
29(34,1 \%)\end{array}$ & $\begin{array}{l}53,1 \pm 19,5 \\
25(71,4 \%)\end{array}$ & $\begin{array}{l}\mathrm{p}<0,001 \\
\mathrm{p}<0,001\end{array}$ \\
\hline діаметр ПШ, см & $2,5 \pm 0,3$ & $2,9 \pm 0,4$ & $\mathrm{p}<0,001$ \\
\hline $\mathrm{e}^{\prime}$ септ, cм/c & $5,2 \pm 1,3$ & $4,1 \pm 0,6$ & $\mathrm{p}<0,001$ \\
\hline е’ лат, см/с & $6,6 \pm 1,8$ & $4,7 \pm 0,7$ & $\mathrm{p}<0,001$ \\
\hline e' середн, см/с & $5,9 \pm 1,5$ & $4,4 \pm 0,5$ & $\mathrm{p}<0,05$ \\
\hline Е/e' спокою, у.о. & $13,2 \pm 1,9$ & $16,3 \pm 1,8$ & $\mathrm{p}<0,01$ \\
\hline 9-13 y.o., (n, \%) & $47(55,3 \%)$ & 0 & $\mathrm{p}<0,001$ \\
\hline$>13$ y.o., $(n, \%)$ & $38(44,3 \%)$ & $35(100 \%)$ & $\mathrm{p}<0,001$ \\
\hline ШТР, м/с & $2,9 \pm 0,3$ & $3,6 \pm 0,7$ & $\mathrm{p}<0,001$ \\
\hline ЕЗВД, \% & $9,3 \pm 5,2$ & $7 \pm 5,2$ & $\mathrm{p}=0,008$ \\
\hline брСАТ мм.рт.ст. & $143 \pm 11,6$ & $148,4 \pm 10,6$ & $\mathrm{p}=0,002$ \\
\hline брДАТ мм.рт.ст. & $85,3 \pm 11,2$ & $86,7 \pm 7,1$ & н/д \\
\hline $\begin{array}{l}\text { брПАТ, мм.рт.ст. } \\
>50 \text { мм.рт.ст., \% }\end{array}$ & $\begin{array}{l}57,4 \pm 8,7 \\
51(60 \%)\end{array}$ & $\begin{array}{l}62,3 \pm 7,4 \\
31(88,6 \%)\end{array}$ & $\begin{array}{l}\mathrm{p}<0,001 \\
\mathrm{p}<0,001\end{array}$ \\
\hline Еа мм.рт.ст./мл & $1,8 \pm 0,6$ & $2,2 \pm 0,8$ & $\mathrm{p}<0,001$ \\
\hline Es мм.рт.ст./мл & $3,1 \pm 2,5$ & $2,7 \pm 1,1$ & н/д \\
\hline $\mathrm{Ea} / \mathrm{Es}$ & $0,77 \pm 0,35$ & $0,84 \pm 0,22$ & $\mathrm{p}=0,002$ \\
\hline АТ серед мм.рт.ст. & $108,3 \pm 10,6$ & $111,6 \pm 8,1$ & н/д \\
\hline САК мл/мм.рт.ст. & $1,3 \pm 0,3$ & $1,2 \pm 0,4$ & $\mathrm{p}=0,013$ \\
\hline ССО мм.рт.ст./мл & $1,8 \pm 0,4$ & $1,9 \pm 0,7$ & н/д \\
\hline ТЗЛА, мм.рт.ст. & $18,3 \pm 2,4$ & $22 \pm 2,4$ & $\mathrm{p}<0,001$ \\
\hline ТПГ, мм.рт.ст. & $13,8 \pm 6,4$ & $31,1 \pm 17,8$ & $\mathrm{p}<0,001$ \\
\hline $\begin{array}{l}\text { Середній градієнт трикуспідальної } \\
\text { регургітації, мм.рт.ст. }\end{array}$ & $27,1 \pm 7,5$ & $47,1 \pm 18,8$ & $\mathrm{p}<0,001$ \\
\hline
\end{tabular}


K. Cherniaieva, Y. Rudenko, G.Mostbauer, A. Bezrodniy, M. Shevchuk, A. Sablin, Y. Moskalenko, E. Kovtun Indicators of structural and functional changes in the myocardium as predictors of the atrial fibrillation in patients with heart failure and preserved ejection fraction

Таблиця 3. Зв’язок між структурно-функціональними параметрами лівого шлуночка та наявністю фібриляції передсердь у гіпертензивних хворих з СНзбФВ

\begin{tabular}{|l|c|c|}
\hline Параметр & Коефіцієнт кореляції & Рівень значимості, $\mathrm{p}$ \\
\hline ІОЛП мл/м & $\rho=0,547$ & $\mathrm{p}<0,01$ \\
\hline $\mathrm{e}^{\prime}$ середнє, см/с & $\rho=-0,557$ & $\mathrm{p}<0,01$ \\
\hline Е/e' & $\rho=0,568$ & $\mathrm{p}<0,01$ \\
\hline ШТР, м/с & $\rho=0,511$ & $\mathrm{p}<0,01$ \\
\hline
\end{tabular}

Ea, Ea/Ees та САК у пацієнтів обох груп, 3 більш вираженими змінами в групі з ФП $(2,2 \pm 0,8 ; 0,84 \pm 0,22$ і $1,2 \pm 0,4$, відповідно) порівняно з пацієнтами з синусовим ритмом $(1,8 \pm 0,6 ; 0,77 \pm 0,35$ і $1,3 \pm 0,3$, відповідно), $\mathrm{p}<0,001-0,01$. Варто відзначити, що зіставність обстежених груп пацієнтів 3 різними генотипами за статтю, віком, частотою цукрового діабету і середнім брахіальним АТ дозволяє виключити значущість цих факторів у порушенні пружно-еластичних властивостей. Розвиток ФП у пацієнтів з СНзбФВ у нашому дослідженні, ймовірно, було обумовлено, підвищенням пульсового навантаження на ЛШ, його гіпертрофії, за даними IMМЛШ, та поглибленню діастолічної дисфункції.

Згідно рекомендацій ЄТК 2016 р. по оцінці діастолічної функції ЛШ, основними показниками, які враховуються при встановленні ДД ЛШ є ІОЛП, Е/е', е'середнє, ШТР (Otsuki T. et al., 2006). У обстежених нами пацієнтів з СНзбФВ виявлено значущий кореляційний зв'язок між цими параметрами та наявністю ФП, що підтверджує схожі патогенетичні механізми ФП, як основної кардіальної коморбідності, та СНзбФВ (таблиця 3). Цікавим $€$ той факт, що об’ємне перевантаження міокарда за даними КДІ, КСІ та УІ, що має істотний вплив на всі параметри ДД ЛШ у пацієнтів з синусовим ритмом, втрачає своє значення з приєднанням ФП. Навпаки, відмічається внесок у розвиток ФП резистивного навантаження, за даними
Еа та ССО (таблиця 4). Це можна пояснити тим, що саме резистивне навантаження на ЛШ та ЛП притаманно пацієнтам з СНзбФВ, що дає змогу вважати, що ФП у обстежених нами хворих є вторинною відносно до СН. Таке припущення підкріплено анамнестичними даними, згідно яких більший відсоток хворих 45,7\% мали симптоми СН до моменту виникнення ФП, порівняно з тими, де ФП передувала $\mathrm{CH}-14,3 \%$, діагностована одночасно з $\mathrm{CH}-17,1 \%$, або невідомої давності - 22,8\%. Використаний підхід до розподілу хворих та отримані результати є співставними з проведеними раніше популяційними дослідженнями (Hijazi Z. et al., 2013). Відсутність кореляційного зв'язку між важкістю СНзбФВ згідно середнього ФК NYHA та параметрами ДД ЛШ, у пацієнтів з ФП, вказує на те, що «симптомність» у таких хворих, обумовлена не тільки присутністю ФП на фоні CH. Дійсно, за даними нашого обстеження, виявлено значно більший вплив некардіальної коморбідної патології (ЦД 2 типу, анемії, ХЗН, ХОЗЛ) на розвиток ФП на фоні СНзбФВ (таблиця 4).

Дослідивши основні структурні та функціональні показники, які мають вплив на розвиток ФП у хворих на СНзбФВ, методом Roc-аналізу було виявлено орієнтовні порогові значення, при яких достовірно збільшується частота виявлення фібриляції передсердь (таблиця 5). Виявлено, що параметри діастолічної дисфункції ЛШ, а саме ІОЛП $>40$ мл/ $\mathrm{M}^{2}$ та 
K. Cherniaieva, Y. Rudenko, G.Mostbauer, A. Bezrodniy, M. Shevchuk, A. Sablin, Y. Moskalenko, E. Kovtun Indicators of structural and functional changes in the myocardium as predictors of the atrial fibrillation in patients with heart failure and preserved ejection fraction

\begin{tabular}{|c|c|c|c|c|c|c|}
\hline \multirow[b]{2}{*}{ Параметр } & \multicolumn{3}{|c|}{ Група $1(n=85)$} & \multicolumn{3}{|c|}{ Група $2(n=35)$} \\
\hline & $\begin{array}{l}\text { ІОЛП, } \\
\text { мл/м² }\end{array}$ & 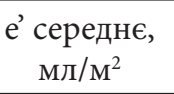 & E/e', y.o. & $\begin{array}{l}\text { ІОЛП, } \\
\text { мл/м }{ }^{2}\end{array}$ & $\begin{array}{c}\text { e' середнє, } \\
\text { мл/ } \mathbf{M}^{2}\end{array}$ & $\begin{array}{l}\text { E/e', } \\
\text { y.o. }\end{array}$ \\
\hline ІОЛП, мл/м² & - & $-0,413^{\star \star}$ & $0,506^{\star *}$ & - & $-0,296^{\star *}$ & $0,441^{\star \star}$ \\
\hline КДІ, мл/м² & $0,159^{*}$ & $-0,207^{\star \star}$ & $0,246^{\star *}$ & 0,016 & 0,014 & $-0,092$ \\
\hline KCI, мл/ $/ \mathrm{M}^{2}$ & $0,158^{*}$ & $-0,290^{\star *}$ & $0,279^{\star *}$ & $-0,087$ & $-0,007$ & $-0,141$ \\
\hline УІ, мл/м² & 0,106 & $-0,083$ & $0,157^{*}$ & $-0,056$ & $0,231^{\star *}$ & $-0,277^{\star}$ \\
\hline ФВ ЛШ, \% & $-0,202^{\star *}$ & $0,414^{* *}$ & $-0,323^{\star *}$ & $-0,162^{*}$ & 0,111 & $-0,252^{*}$ \\
\hline ІММЛШ, г/м² & $0,220^{\star *}$ & $-0,204^{\star *}$ & $0,180^{\star *}$ & $-0,091$ & 0,105 & $-0,318^{\star *}$ \\
\hline $\mathrm{E} \mathrm{cM} / \mathrm{c}$ & $0,185^{\star \star}$ & $-0,077$ & $0,212^{\star \star}$ & $0,175^{\star}$ & 0,023 & $-0,013$ \\
\hline E септ, cм/c & $-0,392^{\star *}$ & $0,835^{\star *}$ & $-0,493^{\star *}$ & $-0,018$ & $0,342^{\star *}$ & $-0,712^{\star *}$ \\
\hline Е лат, см/с & $-0,403^{\star *}$ & $0,839^{\star *}$ & $-0,648^{\star *}$ & $-0,421^{\star *}$ & $0,658^{\star *}$ & $-0,763^{\star *}$ \\
\hline Е серед, см/с & $-0,413^{\star *}$ & - & $-0,605^{\star *}$ & $-0,296^{* *}$ & - & $-0,511^{\star *}$ \\
\hline Е/е спокою, у.о. & $0,506^{\star *}$ & $-0,605^{\star \star}$ & - & $0,386^{* *}$ & $-0,511^{\star *}$ & - \\
\hline Еа мм.рт.ст./мл & 0,038 & 0,030 & $-0,117$ & 0,134 & $-0,191^{\star}$ & $0,492^{\star \star}$ \\
\hline Es мм.рт.ст./мл & $-0,114$ & $0,287^{\star *}$ & $-0,189^{\star *}$ & 0,066 & 0,040 & $0,228^{*}$ \\
\hline $\mathrm{Ea} / \mathrm{Es}$ & 0,128 & $-0,312^{\star *}$ & $0,222^{\star *}$ & 0,085 & $-0,275^{\star}$ & $-0,001$ \\
\hline САК мл/ мм.рт.ст. & $-0,01$ & 0,043 & 0,022 & 0,126 & 0,108 & $-0,181^{\star}$ \\
\hline ССО мм.рт.ст./мл & $-0,017$ & 0,033 & $-0,043$ & $-0,060$ & $-0,171^{\star}$ & $0,164^{*}$ \\
\hline Діаметр ПШ, см & $0,212^{\star \star}$ & $-0,114$ & 0,123 & 0,154 & $-0,293^{\star \star}$ & $0,238^{\star}$ \\
\hline ШТР, м/с & $0,172^{*}$ & $-0,420^{\star *}$ & $0,371^{\star *}$ & $0,339^{\star *}$ & $-0,304^{\star *}$ & $0,525^{\star *}$ \\
\hline СТЛА, мм.рт.ст. & $0,303^{\star *}$ & $-0,412^{\star \star}$ & $0,449^{\star *}$ & $0,352^{\star *}$ & $-0,317^{\star \star}$ & $0,538^{\star *}$ \\
\hline ТЗЛК, мм.рт.ст. & $0,506^{\star \star}$ & $-0,605^{\star *}$ & $0,542^{\star *}$ & $0,441^{\star \star}$ & $-0,511^{\star *}$ & $0,511^{\star *}$ \\
\hline ТПГ, мм.рт.ст. & $0,165^{\star}$ & $-0,215^{\star *}$ & $0,449^{* *}$ & $0,339^{\star *}$ & $-0,304^{* *}$ & $0,548^{* *}$ \\
\hline $\begin{array}{l}\text { Серед градієнт на ЛК, } \\
\text { мм.рт.ст. }\end{array}$ & $0,303^{\star *}$ & $-0,412^{\star *}$ & $-0,452^{\star *}$ & $0,341^{* *}$ & $-0,327^{\star *}$ & $-0,448^{\star *}$ \\
\hline Дистанція 6-хв ходьби, м & $-0,365^{\star *}$ & $0,493^{\star \star}$ & $0,562^{\star \star}$ & $-0,338^{\star *}$ & $0,294^{\star *}$ & $0,298^{\star *}$ \\
\hline NT-proBNP, пг/мл & $0,513^{* *}$ & $-0,548^{\star *}$ & $0,485^{\star *}$ & $0,207^{\star *}$ & $-0,351^{\star *}$ & $0,244^{*}$ \\
\hline ШКФ,мл/хв/1,73м ${ }^{2}$ & $-0,069$ & 0,118 & $-0,020$ & $-0,205^{\star *}$ & $0,316^{* *}$ & $0,654^{*}$ \\
\hline ХОЗЛ & 0,029 & 0,035 & $-0,166^{\star *}$ & $0,269^{\star *}$ & $-0,245^{\star *}$ & $0,197^{\star}$ \\
\hline ЦД 2 тип & 0,008 & 0,003 & $-0,068$ & $0,429^{* *}$ & $-0,015$ & $0,336^{* *}$ \\
\hline Анемія & $0,168^{*}$ & $-0,099$ & $0,150^{*}$ & $0,158^{*}$ & $-0,349^{\star *}$ & $0,321^{\star *}$ \\
\hline
\end{tabular}

Примітка: ${ }^{\star}-\mathrm{p}<0,05 ;{ }^{* *}-\mathrm{p}<0,01 ;{ }^{* *}-\mathrm{p}<0,001$

співвідношення Е/е’>14,75 у.о., збільшують ризик виникнення ФП у пацієнтів 3 доведеною, згідно діючим рекомендаціям Української асоціації кардіологів та ЄТК, серцевою недостатністю зі збереженою ФВ ЛШ. Більша судинна та шлуночкова жорсткість теж з високою достовірністю впливають на розвиток ФП з орієнтовними пороговими значеннями $>1,68$ та > 2,35, відповідно. Нами була доведена діагностична цінність доволі простого методу оцінки ендотеліальної дисфункції - манжеточної проби. Ендотелій-залежна вазодилатація з приростом діаметру після компресії < 10\% достовірно мала 3в'язок з наявністю ФП у пацієнтів з СНзбФВ.

Ще одним питанням, яке і досі не вирішено остаточно, $є$ рівень біомаркеру $\mathrm{CH}$ - NT-proBNP, який часто перевищує значення, встановлені для СНзбФВ, у когор- 
тах пацієнтів з пароксизмальною і постійною ФП (Shantsila E. et al., 2013; Pai R.G. et al., 2003). McKelvie та співдослід. описали п'ятикратне збільшення рівня натрійуретичного пептиду у пацієнтів з СНзбФВ та фібриляцією передсердь у порівнянні з пацієнтами з СНзбФВ при синусовому ритмі (McKelvie et al., 2010). Врахувавши результати проведеного статистичного аналізу, ми припускаємо, що рівень NTproBNP > 600 пг/мл свідчить про таке об'ємне перевантаження лівого передсердя, яке здатно створити морфологічний субстрат для запуску фібриляції передсердь у хворих з СНзбФВ.

Ниркова дисфункція, як одна з найбільш поширених супутніх патологій при серцевій недостатності зі збереженою фракцією викиду (Cleland J.G. et al., 2014), була розглянута як окремий фактор ризику, тому що навіть легке порушення функції нирок пов'язано з підвищеним серцево-судинним (СC) ризиком (Shite J. et al., 1993) за рахунок порушення структури i функції серця. Результати поперечних зрізів в загальній популяції і групі населення 3 гіпертонічною хворобою демонструють високу поширеність гіпертрофії ЛШ у пацієнтів зі зниженою ШКФ. Однак до сих пір недостатньо даних про взаємозв'язок між дисфункцією нирок і структурним та електрофізіологічним ремоделюванням серця, які розглядаються як основа розвитку ФП, у пацієнтів з СНзбФВ (Lund L. et al., 2014). Отримані нами результати вказують на те, що навіть початкове зниження ШКФ, що у випадку обстежених нами хворих становило $<70$ мл/хв/1,73м², відзначалось збільшенням випадків виявлення ФП у пацієнтів з СНзбФВ.

Результати проведеного нами дослідження знаходять підтвердження у матеріалах роботи К.М. Амосової та співдослід., в частині вивчення неінвазивної оцінки тиску наповнення лівого шлуночка. Пацієнти, включені до зазначеної роботи були так само проаналізовані за критеріями ЄТК (2016) по діагностиці СНзФВ ЛШ і поділені на 3 групи, де СНзбФВ була відсутня у 11 (10,6\%) пацієнтів з рівнем NTproBNP меншим за 125 пг/мл (група 1); у 92 (89,3\%) хворих відмічалось збільшення цього маркеру міокардіального стресу та були наявні структурні критерії СН, з котрих у 28 (30,4\%) були відсутні функціональні критерії (група 2), у 64 (69,5\%), окрім структурних критеріїв, були встановлені за даними тканинної доплерографії Е/e' >13 у.о. та е' середнє < $9 \mathrm{~cm} / \mathrm{c}$ (група 3).

Пацієнти всіх трьох груп не відрізнялись за середнім віком, статтю, частотою хронічних форм ішемічної хвороби серця (IXC), зокрема післяінфарктного кардіосклерозу (всі р>0,05). СН II функціональнго класу (ФК) за NYHA встановили у 100\% пацієнтів 1 групи і переважної більшості другої групи $(78,5 \%, \mathrm{p}<0,01)$. Третя група відрізнялась від другої переважанням пацієнтів з III ФК (64,0\% проти $21,4 \%$, $\mathrm{p}<0,01)$ і меншою часткою II ФК $(35,9 \%$, $\mathrm{p}<0,01)$. За середньою дистанцією шестихвилинної ходи пацієнти 1 та 2-ї груп не відрізнялись, однак вона була суттєво меншою в групі 3 (на 52\% та 42,2\%, відповідно, $\mathrm{p}<0,01)$. Таким чином зрозуміло, що $\mathrm{CH}$ була важчою у хворих 3-ї групи. ІММЛШ $(\mathrm{p}<0,05$ та $\mathrm{p}<0,01)$ збільшувався від групи 1 до групи 3, так само, як і ІОЛП (всі $\mathrm{p}<0,01$ ), та становив $45,7 \pm 7,4$ мл/ $\mathrm{M}^{2}$.

Значна дилатація лівого передсердя, за даними середньої величини ІОЛП, є наслідком тривалого і вираженого підвищення тиску в ньому, що ймовірно, сприяло розвитку ФП. Випадки останньої зустрічались практично виключно в хворих групи 3 , в котрій іï частота склала $45 \%$, що відповідає даним літератури відносно іiі частоти при хронічній СНзФВ ЛШ (Амосова К.М. та співдослід., 2018). 
K. Cherniaieva, Y. Rudenko, G.Mostbauer, A. Bezrodniy, M. Shevchuk, A. Sablin, Y. Moskalenko, E. Kovtun Indicators of structural and functional changes in the myocardium as predictors of the atrial fibrillation in patients with heart failure and preserved ejection fraction

Таблиця 5. Частота виявлення ФП залежно від рівня окремих показників та їх прогностична оцінка

\begin{tabular}{|c|c|c|c|c|}
\hline Ознаки & Групи & $\begin{array}{l}\text { Частота ФП у } \\
\text { відповідних } \\
\text { групах n/N (\%) }\end{array}$ & $\begin{array}{l}\text { Відношення } \\
\text { шансів, OR } \\
\text { (95\%ДI) }\end{array}$ & $\mathbf{P}\left(\chi^{2}\right)$ \\
\hline \multirow{2}{*}{ Вік 65 р. } & $>65$ & $21 / 65(32,3 \%)$ & \multirow{2}{*}{$1,4(0,63-3,1)$} & \multirow{2}{*}{$\mathrm{p}=0,411$} \\
\hline & $<65$ & $14 / 55(25,5 \%)$ & & \\
\hline \multirow{2}{*}{ NTproBNP >600 пг/мл } & $>600$ & $33 / 55(60,0 \%)$ & \multirow{2}{*}{$47,3(10,46-213,4)$} & \multirow{2}{*}{$\mathrm{p}=0,0001$} \\
\hline & $<600$ & $2 / 65(3,1 \%)$ & & \\
\hline \multirow{2}{*}{ ІОЛП >40 мл/ $\mathrm{m}^{2}$} & $>40$ & $29 / 45(64,4 \%)$ & \multirow{2}{*}{$20,8(7,41-58,6)$} & \multirow{2}{*}{$\mathrm{p}=0,0001$} \\
\hline & $<40$ & $6 / 75(8,0 \%)$ & & \\
\hline \multirow{2}{*}{ IMT >35 кг $/ \mathrm{M}^{2}$} & $>35$ & $8 / 17(47,1 \%)$ & \multirow{2}{*}{$2,5(0,88-7,1)$} & \multirow{2}{*}{$\mathrm{p}=0,080$} \\
\hline & $<65$ & $27 / 103(26,2 \%)$ & & \\
\hline \multirow{2}{*}{ E/e' $>14,75$ y.o. } & $>14.75$ & $27 / 42(64,3 \%)$ & \multirow{2}{*}{$15,8(5,99-41,4)$} & \multirow{2}{*}{$\mathrm{p}=0,0001$} \\
\hline & $<14.75$ & $8 / 78(10,3 \%)$ & & \\
\hline \multirow{2}{*}{ IMМЛШ>200 г/м² } & $>200$ & $11 / 29(37,9 \%)$ & \multirow{2}{*}{$1,7(0,71-4,1)$} & \multirow{2}{*}{$\mathrm{p}=0,233$} \\
\hline & $<200$ & $24 / 91(26,4 \%)$ & & \\
\hline \multirow{2}{*}{$\mathrm{Ea}>1,68$} & $>1.68$ & $33 / 79(41,8 \%)$ & \multirow{2}{*}{$14,0(3,15-62,1)$} & \multirow{2}{*}{$\mathrm{p}=0,0001$} \\
\hline & $<1.68$ & $2 / 41(4,9 \%)$ & & \\
\hline \multirow{2}{*}{$\mathrm{Es}>2,35$} & $>2.35$ & $22 / 64(34,4 \%)$ & \multirow{2}{*}{$1,65(0,8-3,8)$} & \multirow{2}{*}{$\mathrm{p}=0,218$} \\
\hline & $<2.35$ & $13 / 56(23,2 \%)$ & & \\
\hline \multirow{2}{*}{ ШКФ <70 мл/хв/1,73м² } & $<70$ & $25 / 62(40,3 \%)$ & \multirow{2}{*}{$3,2(1,39-7,6)$} & \multirow{2}{*}{$\mathrm{p}=0,005$} \\
\hline & $>70$ & $10 / 58(17,2 \%)$ & & \\
\hline \multirow{2}{*}{$\mathrm{D} 1 / \mathrm{D} 2<10 \%$} & $<10 \%$ & $27 / 73(37,0 \%)$ & \multirow{2}{*}{$2,9(1,17-7,0)$} & \multirow{2}{*}{$\mathrm{p}=0,019$} \\
\hline & $>10 \%$ & $8 / 47(17,0 \%)$ & & \\
\hline
\end{tabular}

Примітка: відношення шансів виявлення ФП в групі в чисельнику у порівнянні з групою в знаменнику.

Отримані порогові значення мають доволі високу чутливість та специфічність: ІОЛП - 82,8\% та 81,2\%, відповідно, 3 позитивною предикторною цінністю - 64,4\%; Е/е' - 77,1\% та 82,3\%, відповідно, з позитивною предикторною цінністю - 64,3\%.

\section{Висновки.}

1. У пацієнтів з серцевою недостатністю і збереженою ФВ ЛШ знижена толерантність до фізичного навантаження за результатами визначення дистанції 6-тихвилинної ходьби, важчий ФК по класифікації NYHA та вищий рівень NTproBNP асоціюються з більш високою частотою розвитку фібриляції передсердь.

2. Поява супутньої ФП у пацієнтів з серцевою недостатністю і збереженою ФВ ЛШ достовірно асоціюється зі збільшенням тиску наповнення лівого шлуночка, порушенням ендотелій-залежної вазодилатації та початковим зниженням швидкості клубочкової фільтрації.

3. Показники збільшеного тиску наповнення лівого шлуночка, з орієнтовними пороговими значеннями ІОЛП $>40 \mathrm{mл} / \mathrm{M}^{2}$ та E/e’>14,75 у.о. мають значну прогнос- 
K. Cherniaieva, Y. Rudenko, G.Mostbauer, A. Bezrodniy, M. Shevchuk, A. Sablin, Y. Moskalenko, E. Kovtun Indicators of structural and functional changes in the myocardium as predictors of the atrial fibrillation in patients with heart failure and preserved ejection fraction

тичну цінність та можуть бути використані для скринінгу пацієнтів з СНзбФВ для визначення хворих з високим ризиком розвитку ФП.

Авторські внески: «концепція, К.Ч. і Ю.Р.; методологія, К.Ч., Ю.Р., А.Б., М.Ш.; програмне забезпечення; валідація, А.Б., Ю.Р., К.Ч..; формальний аналіз, К.Ч.; дослідження, К.Ч., Ю.Р., А.Б., М.Ш., Ю.М.; ресурси, Г.М., Є.А., А.С.; курація даних, К.Ч., Ю.М., М.Ш., Є.А.; огляд та редагування, А.Б., Ю.В., Г.М.; візуалізація К.Ч., А.Б.

\section{ЛІТЕРАТУРА}

Afshinnia F., Spitalewitz S., Chou S.Y. et al. (2007) Left ventricular geometry and renal function in hypertensive patients with diastolic heart failure. Am J Kidney Dis., 49(2), p. 227-236, DOI: 10.1053/j.ajkd.2006.10.021.

Ahmed A., Rich M.W., Sanders P.W. et al. (2007) Chronic kidney disease associated mortality in diastolic versus systolic heart failure: a propensity matched study. Am J Cardiol., 99(3), p. 393-398, DOI: 10.1016/j.amjcard.2006.08.042.

ATS Statement. Guidelines for the six-minute walk test (2002) Amer. J. Respir. Critical Care Medicine., 166 (1), p. 111-117, DOI: 10.1164/ajrccm.166.1.at1102.

Borlaug B.A., Kass D.A. (2011) Ventricular-vascular interaction in heart failure. Cardiol. Clin., 29, p. 447-459, DOI: 10.1016/j.hfc.2007.10.001.

Cleland J. G., Pellicori P., Dierckx R. (2014) Clinical trials in patients withheart failure and preserved left ventricular ejection fraction. HeartFail. Clin., 10, p. 511 - 523, DOI: 10.1016/j.hfc.2014.04.011.

Hallan S., Astor B., Romundstad S. et al. (2007) Association of kidney function and albuminuria with cardiovascular mortality in older vs younger individuals: The HUNT II Study. J Arch Intern Med., 167(22), p. 2490-2496, DOI: 10.1001/ archinte.167.22.2490.

Hijazi Z., Wallentin L., Siegbahn A. et al. (2013) N-terminal pro-B-type natriuretic peptide for risk assessment in patients with atrial fibrillation: insights from the ARISTOTLE Trial (Apixaban for the Prevention of Stroke in Subjects With Atrial Fibrillation). J Am Coll Cardiol., 61(22), p. 2274-2284, DOI: 10.1016/j.jacc.2012.11.082.

Knackstedt C., Gramley F., Schimpf T. et al. (2008) Association of echocardiographic atrial size and atrial fibrosis in a sequential model of congestive heart failure and atrial fibrillation. Cardiovasc Pathol., 17, p. 318-324, DOI:10.1016/j.carpath.2007.12.003.

Kotecha D., Lam C.S.P., Van Veldhuisen D.J. et al. (2016)Heart Failure With Preserved Ejection Fraction and Atrial Fibrillation: Vicious Twins. Journal of the American College of Cardiology, 68 (20), p. 2217-2228, DOI: 10.1016/j. jacc.2016.08.048.

Kristensen S.L., Mogensen U.M., Jhund P.S., et al. (2019) N-terminal pro-B-type natriuretic peptide levels for risk prediction in patients with heart failure and preserved ejection fraction according to atrial fibrillation status. Circ Heart Fail., 12(3), p. 5766, DOI: 10.1161/CIRCHEARTFAILURE.118.005766.

Lam C.S., Donal E., Kraigher-Krainer E., Vasan R.S. et al. (2011) Epidemiology and clinical course of heart failure with preserved ejection fraction. Eur J Heart Fail, 13, p. 18-28, DOI: 10.1093/eurjhf/hfq121.

Lang R. M., Bierig M., Devereux R. B., Flachskampf F. A. (2006) Recommendations for chamber quantification. Eur J Echocardiography, 7, p. 79-108, DOI: 10.1016/j.euje.2005.12.014.

Lund L. H., Donal E., Oger E. et al. (2014) Association between cardiovascular vs. non-cardiovascular co-morbidities and outcomes in heart ailure with preserved ejection fraction. Eur. J. Heart Fail.,16, p. 992 - 1001, DOI: 10.1002/ejhf.137.

Manning W.J., Silverman D.I., Katz S.E. et al. (1994) Impaired left atrial mechanical function after cardioversion: relation to the duration of atrial fibrillation. J Am Coll Cardiol., 23, p. 1535-1540, DOI: 10.1016/0735-1097(94)90652-1.

McKelvie R.S., Komajda M., McMurray J. et al. (2010) Baseline plasma NT-proBNP and clinical characteristics: results from the irbesartan in heart failure with preserved ejection fraction trial. J Card Fail., 16(2), p.128-134, DOI: 10.1016/j. cardfail.2009.09.007.

Melenovsky V., Borlaug B.A., Rosen B., et al. (2007) Cardiovascular features of heart failure with preserved ejection fraction versus nonfailing hypertensive left ventricular hypertrophy in the urban Baltimore community: the role of atrial remodeling/dysfunction. J Am Coll Cardiol., 49, p. 198-207, DOI: 10.1016/j.jacc.2006.08.050.

Naeije R., Vachiery J.-L., Yerly P. et al. (2013) The transpulmonary pressure gradient for the diagnosis of pulmonary vascular disease. Eur. Respiratory J., 41, p.217-223, DOI:10.1183/09031936.00074312.

Nagueh S.F., Appleton C.P., Gillebert T.C. et al. (2009) Recommendations for the evaluation of left ventricular diastolicfunction by echocardiography. J. Am. Soc. Echocardiogr., 22 (2), p. 107-133, DOI: 10.1016/j.echo.2008.11.023.

O'Neal W.T., Sandesara P., Patel N. et al. (2017) Echocardiographic predictors of atrial fibrillation in patients with heart failure with preserved ejection fraction. Eur Heart J Cardiovasc Imaging, 18(7), p.725-729, DOI: 10.1093/ehjci/jex038.

Otsuki T., Maeda S., Iemitsu M. et al. (2006) Contribution of systemic arterial compliance and systemic vascular resistance to effective arterial elastance changes during exercise in humans. Acta Physiol (Oxf), 188, p.15-20, DOI: 10.1111/j.1748-1716.2006.01596.x. 
K. Cherniaieva, Y. Rudenko, G.Mostbauer, A. Bezrodniy, M. Shevchuk, A. Sablin, Y. Moskalenko, E. Kovtun Indicators of structural and functional changes in the myocardium as predictors of the atrial fibrillation in patients with heart failure and preserved ejection fraction

Pai R.G., Varadarajan P., Tanimoto M. (2003) Effect of atrial fibrillation on the dynamics of mitral annular area. J Heart Valve Dis., 12, p. 31-37. Retrieved from https://www.icr-heart.com/?cid=1179.

Ponikowski P., Voors A.A., Anker S.D. et al. (2016) ESC Guidelines for the diagnosis and treatment of acute and chronic heart failure. Eur. Heart J., 37 (27), p. 2129-2200, DOI: 10.1093/eurheartj/ehw128.

Quinones MA. (2005) Assessment of diastolic function. Prog Cardiovasc Dis., 47, p. 340-355, DOI: 10.1016/j. pcad.2005.02.009.

Rosita Z., Alanna M. Chamberlain, Véronique L. Roger (2013) Temporal Relationship and Prognostic Significance of Atrial Fibrillation in Heart Failure Patients With Preserved Ejection Fraction. A Community-Based Study. Circulation, 128, p.1085-1093, DOI:10.1161/CIRCULATIONAHA.113.001475.

Shantsila E., Shantsila A., Blann A.D., et al. (2013) Left ventricular fibrosis in atrial fibrillation. Am J Cardiol., 111., p. 996-1001, DOI: 10.1016/j.amjcard.2012.12.005.

Shite J., Yokota Y., Yokoyama M. (1993) Heterogeneity and time course of improvement in cardiac function after cardioversion of chronic atrial fibrillation: assessment of serial echocardiographic indices. Br Heart J., 14, p. 154-159, DOI: 10.1136/hrt.70.2.154

van den Berg M.P., van Gelder I.C., van Veldhuisen D.J. (2004) Depletion of atrial natriuretic peptide during longstanding atrial fibrillation. Europace, 6, p. 433-437, DOI: 10.1016/j.eupc.2004.04.006.

Vermond R.A., Geelhoed B., Verweij N. et al. (2015) Incidence of atrial fibrillation and relationship with cardiovascular events, heart failure, and mortality: a community-based study from the Netherlands. J Am Coll Cardiol., 66. p. 1000-1007, DOI: $10.1016 /$ j.jacc.2015.06.1314.

Williams B., Mancia G., Spiering W. et al. (2018) ESC/ESH Guidelines for the management of arterial hypertension. Eur Heart J., 39(33), p. 3021-3104, DOI: 10.1093/eurheartj/ehy339.

Zile M.R., Baicu C.F., Ikonomidis J.S., et al. (2015) Myocardial stiffness in patients with heart failure and a preserved ejection fraction: contributions of collagen and titin. Circulation, 131, p. 1247-1259, DOI: 10.1161/CIRCULATIONAHA.114.013215.

Амосова Е. Н., Черняева Е.И., Руденко Ю.В. и др. (2018) Фенотип-ориентированный подход к клинической оценке пациентов с хронической сердечной недостаточностью с сохраненной фракцией выброса левого желудочка. Серце і судини, 3, С. 76-83. Режим доступу: http://nbuv.gov.ua/UJRN/sis_2018_3_10.

Амосова К. М., Василенко О. В., Руденко Ю.В., Безродний А.Б. (2018) Значущість неінвазивної оцінки підвищення тиску наповнення лівого шлуночка у пацієнтів з артеріальною гіпертензією, гіпертрофією лівого шлуночка, симптомами серцевої недостатності та збереженою фракцією викиду в реальному житті. Український терапевтичний журнал, 2, С. 5-13. DOI:10.30978/UTJ2018-2-5. 


\title{
INDICATORS OF STRUCTURAL AND FUNCTIONAL CHANGES IN THE MYOCARDIUM AS PREDICTORS OF THE ATRIAL FIBRILLATION IN PATIENTS WITH HEART FAILURE AND PRESERVED EJECTION FRACTION
}

\section{Cherniaieva Kateryna}

Assistant, Department of internal medicine № 2, O.O. Bogomolets’ National Medical University

\section{Rudenko Yuliia}

Doctor of medical science, professor, Department of internal medicine № 2, O.O. Bogomolets' National Medical University

\section{Mostbauer Galyna}

Candidate of medical science, associate professor, head of the Department of internal medicine № 2, O.O. Bogomolets’ National Medical University

\section{Bezrodniy Andrii}

Candidate of medical science, associate professor, Department of internal medicine № 2, O.O. Bogomolets' National Medical University

\section{Shevchuk Mykhailo}

Assistant, Department of internal medicine № 2, O.O. Bogomolets’ National Medical University

\section{Sablin Andrii}

Head of the myocardial infarction department №2, Oleksandrivska clinical hospital, Kiyv Moskalenko Yuliia

Assistant, Department of internal medicine № 2, O.O. Bogomolets’ National Medical University

\section{Kovtun Evgen}

Assistant, Department of internal medicine № 2, O.O. Bogomolets’ National Medical University

\begin{abstract}
A large number of recent trials suggested that atrial fibrillation (AF) and heart failure (HF) should be considered as two epidemic cardiovascular pathologies that are closely interrelated, each contributing to the development of the other. The purpose of our work was to analyze the peculiarities of the structural and functional parameters of the heart and blood vessels in patients with $\mathrm{HFpEF}$, as well as to determine the most informative predictors of AF and their predictive value. A study of the literature indicates that AF has a close relationship with both HFpEF and the diagnostic criteria used to determine it. The relevance of the study of this pathology is that AF has a significant impact on the course and prognosis of HFpEF. The study was conducted on a case-control design. This work is based on the results of examination of 115 hemodynamically stable patients with arterial hypertension (AH), clinical symptoms and signs of heart failure (HF), with left ventricular (LV) ejection fraction (EF) $\geq$ $50 \%$ and signs of diastolic dysfunction (DD) according to echocardiography data. Patients' age ranged from 40 to 85 years (mean age $66.3 \pm 10.8$ years). For the first time, criteria for LV DD were analyzed as possible predictors of atrial fibrillation in patients with HFpEF and thresholds for some of them were determined. The study empirically confirms and theoretically argues that the presence of atrial fibrillation in patients with HFpEF, in contrast to
\end{abstract}


K. Cherniaieva, Y. Rudenko, G.Mostbauer, A. Bezrodniy, M. Shevchuk, A. Sablin, Y. Moskalenko, E. Kovtun Indicators of structural and functional changes in the myocardium as predictors of the atrial fibrillation in patients with heart failure and preserved ejection fraction

those with sinus rhythm, is associated with a more severe functional class of HF estimated by NYHA classification; higher by $28.1 \%$ NTproBNP level; increased left ventricular filling pressure with LAVI thresholds $>40 \mathrm{ml} / \mathrm{m}^{2}$ and E/e '> 14.75; with impaired endothelium-dependent vasodilation and an initial decrease in glomerular filtration rate. The results of the study may be useful for the screening and detection of AF in patients with established HFpEF, by monitoring of ECG, in case of detection of threshold values of diastolic LV dysfunction.

Key words. Arterial hypertension, arterial stiffness, diastolic dysfunction, heart failure, atrial fibrillation. 